ASIMETRIS: JURNAL PENDIDIKAN MATEMATIKA DAN SAINS

$$
\text { p-ISSN } 2721 \text { - 8724, e-ISSN } 2722 \text { - } 0214
$$

Website Jurnal: http://journal.umuslim.ac.id/index.php/asm/

\begin{tabular}{rll} 
Info Artikel: & Direvisi pada 16 Oktober 2021 \\
Disubmit pada 9 Oktober 2021 & Diterima pada 21 Oktober 2021 \\
Direview pada 15 Oktober 2021 & Tersedia secara daring pada 28 Oktober 2021 \\
\hline
\end{tabular}

\title{
UPAYA PENINGKATAN KEMAMPUAN KONEKSI MATEMATIS SISWA DENGAN MENGGUNAKAN METODE EKSPOSITORI PADA MATERI TRIGONOMETRI
}

\author{
Nurfajriati ${ }^{1}$, Novianti ${ }^{2}$, Wiwin Apriani ${ }^{3}$ \\ 1,2,3 Pendidikan Matematika Universitas Almuslim Bireuen, Aceh, Indonesia \\ Alamat email: Nurfajriati494@gmail.com
}

\begin{abstract}
ABSTRAK. Penelitian ini bertujuan untuk mengetahui kemampuan koneksi matematis siswa dengan menggunakan metode Ekspositori pada materi trigonometri kelas X di MAN 1 Bireuen. Penelitian ini menggunakan pendekatan kualitatif, dengan jenis Penelitian Tindakan Kelas (PTK). Sampel dalam penelitian ini adalah siswa kelas X IPA ${ }^{1}$ berjumlah 25 orang siswa, semester genap tahun ajaran 2020/2021. Dari hasil tes siklus I diperoleh data siswa yang mendapatkan skor $\geq 65$ adalah $64 \%$, sedangkan pada siklus II diperoleh $92 \%$. Dari hasil tersebut terjadi peningkatan sebesar $28 \%$. Hasil observasi aktifitas guru pada siklus I adalah $82,7 \%$ meningkat menjadi $95,4 \%$ pada siklus II. Sedangkan hasil observasi aktivitas siswa siklus I adalah $84,5 \%$ meningkat menjadi $93,6 \%$ pada siklus II termasuk ke dalam kategori sangat baik. Dengan demikian kriteria keberhasilan belajar dan proses pembelajaran siklus II sudah berhasil serta hasil wawancara siswa menunjukkan bahwa siswa senang belajar matematika pada materi trigonometri melalui metode Ekspositori. Hal ini dapat disimpulkan bahwa metode pembelajaran Ekspositori yang telah dilaksanakan dapat meningkatkan kemampuan koneksi matematis siswa pada materi trigonometri kelas XIPA 1 di MAN 1 Bireuen.
\end{abstract}

Kata Kunci: Koneksi Matematis, Metode Ekspositori, Trigonometri

ABSTRACT. This study aims to determine students' mathematical connection skills using the expository method on trigonometry material for class $X$ at MAN 1 Bireuen. This study uses a qualitative approach, with the type of Classroom Action Research (CAR). The sample in this study were students of class X IPA ${ }^{1}$ totaling 25 students, even semesters for the 2020/2021 academic year. From the results of the first cycle test data obtained by students who get a score is $64 \%$, while in the second cycle it is $92 \%$. From these results there was an increase of $28 \%$. The results of observations of teacher activities in the first cycle we re $82.7 \%$, increasing to $95.4 \%$ in the second cycle. While the results of the observation of student activity in the first cycle was $84.5 \%$, increasing to $93.6 \%$ in the second cycle, which was included in the very good category. Thus the criteria for learning success and the second cycle of the learning process have been successful and the results of student interviews show that students enjoy learning mathematics on trigonometry material through the expository method. It can be concluded that the expository learning method that has been implemented can improve students' mathematical connection skills in the class X IPA ${ }^{1}$ trigonometry material at MAN 1 Bireuen.

Keywords: Mathematical Connection, Expository Method, Trigonometry.

\section{PENDAHULUAN}

Pendidikan adalah salah satu cara yang ditempuh oleh seseorang untuk meningkatkan ilmu pengetahuan, sehingga dapat menjadi orang yang berilmu tinggi dan berguna bagi masyarakat kedepannya. Oleh karena itu, diwajibkan bagi kita untuk terus belajar meningkatkan kualitas pendidikan kita supaya perubahan zaman tidak membuat kita ketinggalan informasi tentang yang terjadi di sekitar kita maupun di luar daerah.

Pendidikan berperan penting untuk menciptakan manusia yang berpotensi, maka dengan pendidikanlah manusia bisa berkembang 
pesat pendewasaannya, sehingga dalam menghadapi suatu masalah yang dihadapi akan diselesaikan dengan tanggung jawab yang besar. Pendidikan sudah sangat berkembang dengan berbagai kecanggihan teknelogi yang semakin zaman semakin tinggi tingkat perkembangannya yang membuat seseorang harus benar-benar berpikir kritis dalam mewujudkan keinginannya untuk mencapai sesuatu di dalam dunia pendidikan.

Matematika adalah salah satu ilmu dari berbagai banyak mata pelajaran yang harus di pelajari oleh seseorang dalam menenpuh dunia pendidikan yang dapat membuat pikiran seseorang mampu berpikir kritis untuk menyelesaikan berbagai masalah hal-hal yang berhubungan dengan dunia pendidikan khususnya dalam bidang ilmu pengetahuan matematika. Matematika juga bisa membuat suatu masalah yang berhubungan kehidupan sehari-hari dengan berbagai kegiatan yang dapat menciptakan sesuatu pemecahan soal masalah yang dapat diselesaikan dengan menggunakan bidang ilmu matematika itu sendiri. Menurut (Novianti \& Khaulah, 2021), "Konsep dasar dalam mempelajari matematika sangat berpengaruh bagi siswa dan harus adanya kesinambungan dan keseimbangan antara konsep yang telah dipelajari terdahulu dengan konsep yang akan dipelajari sekarang. "Salah satu tujuan matematika agar seseorang yang menempuh dunia pendidikan khususnya bidang ilmu matematika agar dapat menyelesaikan masalah-masalah yang mungkin ditemukan pada sesuatu baik itu di dalam kehidupan sehari-hari maupun bukan diluar dari itu diharapkan kepada yang menempuh dunia pendidikan agar mampu menyelesaikan masalah tersebut dengan mengkaitkannya kedalam bidang ilmu pendidikan khususnya di dalam ilmu matematika.

Berdasarkan hasil pengamatan yang didapatkan dari mata pelajaran matematika Zainal Abidin, S.Pd di sekolah MAN 1 Bireuen, mendapat beberapa masalah yang dialami siwa didalam pelajaran matematika khususnya pada materi trigunometri yang harus di selesaikan dengan berbagai cara penyelesaiian sala satunya ketika masalah tersebut dikaitkan kedalam ilmu atau masalah di dalam kehidupan sehari-hari.

Berdasarkan permasalahan di atas, maka peneliti tertarik untuk menggunakan metode pembelajaran ekspositori. Menurut (Suyitno, 2004), metode ekspositori adalah cara penyampaian pelajaran dari seorang guru kepada siswa di dalam kelas dengan cara berbicara di awal pelajaran, menerangkan materi dan contoh soal disertai tanya jawab.

Berdasarkan penelitian terdahulu yang dilakukan oleh (Dewi, 2013), yaitu tentang peningkatan kemampuan koneksi matematis siswa, yang menyatakan bahwa "pembelajaran matematika di sekolah bukan hanya menghafal atau menerapkan secara sederhana rumus matematika yang telah diketahui saja, namun memerlukan Kemampuan Berpikir Matematis Tingkat Tinggi yang akan bermanfaat untuk diri siswa, salah satu bagian dari Kemampuan Berpikir Matematis Tingkat Tinggi adalah Kemampuan Koneksi Matematis yang merupakan suatu alat yang penting untuk matematika dan kehidupan sehari-hari".

Penelitian yang dilakukan oleh (Sanjaya,2019), menyatakan bahwa "kemampuan pemecahan masalah matematis siswa yang memperoleh model pembelajaran berbasis masalah tidak lebih baik darsipada siswa yang memperoleh metode pembelajaran ekspositori".

Berdasarkan latar belakang masalah di atas, dapat disimpulkan bahwa pembelajaran matematika pada materi trigonometri dapat ditingkatkan dengan menggunakan metode pembelajaran ekspositori. Oleh karena itu, Kami tertarik dalam menguji coba suatu penelitian untuk melihat tingkat keberhasilan yang dapat dicapi oleh siwa yang mengikuti penelitian dengan judul "Upaya Peningkatan Kemampuan Koneksi Matematis Siswa dengan menggunakan Metode Ekspositori pada materi Trigonometri kelas X di MAN 1 Bireuen". 


\section{METODE PENELITIAN}

Penelitian ini menggunakan pendekatan kualitatif. Pelaksanaan PTK menurut (Arikunto, 2012) terdiri atas empat tahap, yaitu (1) Perencanaan, (2) Pelaksanaan, (3) Pengamatan, dan (4) refleksi. Keempat tahap tersebut disatukan dalam siklus.

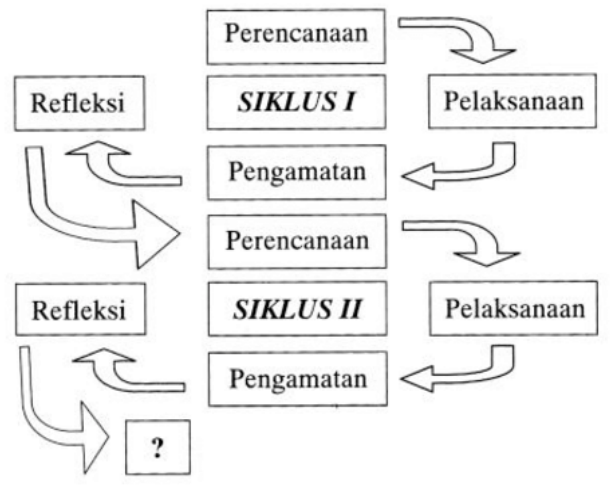

Gambar 2.1. Model Tahapan PTK

\subsection{Tahap-Tahap Penelitian}

Saat ingin melakukan suatu uji coba penelitian otomatis peneliti harus menyiapkan atau suatu perancangan kegiatan untuk mempermudah suatu kegiatan yang dilakukan dalam melaksanakan kegiatan penelitian.

\section{Perencanaan}

a. Terutama hal yang paling harus diperhatikan oleh peneliti yaitu membuat rancangan-rancangan pembelajaran untuk menjalankan suatu penelitian yang akan dilaksanakan untuk mempermudah proses penelitian disesuaikan dengan judul model pembelajaran yang akan dilaksanakan.

b.Menyiapkan beberapa dokumen atau halhal yang ditujukan untuk mengukur keberhasilah siswa untuk menilai hasil yang akan digunakan untuk proses penelitian.

c.Mempersiapkan sesuatu yang dibutuhkan untuk keperluan yang dibutuhkan dalam melakukan suatu penelitian. sarana dan media pembelajaran yang digunakan dalam setiap pembelajaran.

d.Mempersiapkan soal-soal yang akan diuji coba dalam pelaksanaan kegiatan yang dilakukan pada saat pembelajaran untuk mengetahui tingkat keberhasilan seseorang dapat menjadi tolak ukur yang menggunakan metode ekspositori. Dengan begitu peneliti dapat memperoleh informasi yang bisa diambil untuk melihat sampai mana siswa mampu menyelesaikan masalah tersebut.

\section{Pelaksanaan Tindakan}

Pada saat proses pembelajaran terjadi maka peneliti berposisi sebagai guru yang bertindak mengajar sesuai gengan rancangan pembelajaran yang telah disusun dan guru yang membantu peneliti untuk menjalankan tugasnya sebagai teman dari penelitian yang di tetapkan oleh peneliti untuk medokumentasikan beberapa hal yang harus didokumentasikan untuk bahan penelitian yang telah dirancang sebelumnya. Ketika pada proses tindakan terjadi kendalakendala pada saat penelitian maka peneliti ataupun teman penelitiannya dapat mengikuti atau mempersiapkan diri sesuai dengan keadaan yang terjadi dilapangan, agar penelitian dapat berjalan dengan lancar.

\section{Observasi}

Observasi terjadi didalam penelitian yang dapat dilakukan atau dilihat secara langsung oleh pengamat dengan berbagai kegiatan yang terjadi baik yang dilakukan oleh seorang guru peneliti ataupun siswa yang melakukannya dan dapat dinilai dengan menggunakan lembaran-lembaran yang telah dibuat atau dirancang sebelumnya oleh peneliti itu sendiri dan kemudian dinilai oleh teman yang menjadi teman penelitian itu sendiri, dalam melihat proses pembelajaran yang dilakukan didalam kelas pada saat proses penelitian terjadi dengan menerapkan metode ekspositori.

\section{Refleksi}

Refleksi dinilai oleh sang peneliti itu sendiri dan juga teman peneliti untuk dapat melihat hasil dari penelitian dan refleksi dilakukan pada saat penelitian telah selesai dan kemudian hasil refleksi tersebut di analisis kembali untuk melihat keberhasilan penelitian 
yang telah dilakukan oleh peneliti. Jika hasil refleksi tidak mencapai keberhasilan siswa sesuai dangan nilai yang telah ditetapkan maka penelitian harus dilanjutkan ke siklus berikutnya, dan jika hasil refleksi tersebut sudah mencapai kriteria ketuntasan maka penelitian dihentikan. Hasil refleksi dapat menjadi tujuan perbaikan dalam proseb penelitian yang dilakukan oleh peneliti untuk menjadi bahan perbaikan yang dapat memperbaiki ketahap berikutnya, sehingga keberhasilan yang akan ditetapkan mampu mencapi sesuai yang diinginkan dan perbaikan menjadi salah satu tujuan pendidikan.

Penelitian ini dilaksanakan pada saat proses pembelajaran matematika berlangsung di kelas X MAN 1 Bireuen. MAN tersebut beralamat di Desa kide aceh, Kecamatan Samalanga, Kabupaten Bireuen, Aceh. Penelitian dilaksanakan pada tahun 2021. Subyek dalam penelitian ini adalah siswa kelas $X$ MAN 1 Bireuen.

Teknik yang dilakukan pada saat pengumpulan data diambil dari hasil tes yang telah diberikan. Soal-soal yang diberikan berhubungan dengan materi trigonometri yang di sesuaikan dengan judul penelitian untuk dapat menjadi acuan keberhasilan penelitian.

\section{HASIL PENELITIAN DAN PEMBAHASAN 3.1 Temuan penelitian siklus I}

Beberapa temuan yang diperoleh pada pelaksanaan siklus I adalah sebagai berikut:

1. Proses pembelajaran masih pasif, masih banyak siswa yang belum terbiasa mengeluarkan pendapatnya.

2. Masih ada sebagian siswa yang sulit memahami antara rumus-rums perbandingan trigonometri.

3. Pelaksanaan siklus I kriteria hasil belum mencapai kriteria ketuntasan sedangkan kriteria proses sudah mencapai kriteria ketuntasan.

\subsection{Temuan Peneliti Siklus II}

Beberapa temuan yang diperoleh pada pelaksanaan siklus II adalah sebagai berikut:

1. Siswa menjadi lebih aktif dan kritis pada siklus II, banyak siswa yang telah berani mengeluarkan pendapat.

2. Siswa sangat termotivasi belajar dengan menggunakan metode ekspositori Pada materi trigoometri karena dapat meningkatkan kemampuan koneksi matematis siswa.

3. Siswa tidak lagi mengalami kesulitan dalam menyelesaikan soal-soal, hal ini dilihat dari hasil tes akhir yang mengalami peningkatan.

4. Pelaksanaan siklus II sudah mencapai kriteria ketuntasan, baik kriteria proses maupun kriteria hasil.

Berdasarkan uraian hasil penelitian yang didapat pada siklus I maka diperoleh beberapa hasil yang telah dilakukan dari kegiatan penelitian yaitu hasil tes akhir siklus I diperoleh sebesar $64 \%$ dengan jumlah skor yang didapat $\geq 65$. Hal ini menunjukkan bahwa pencapaian dari hasil penelitian yang dilakukan tidak mencapai target yang telah ditetapkan, sehingga peneliti perlu mengulangi kembali penelitian ke siklus berikutnya atau siklus II. Hasil olah dari penelitian atau hasil peninjauan observasi yang dilakukan oleh peneliti dan teman peneliti pada aktivitas kegiatan guru pada hasil siklus I memperoleh dengan nilai skor yang telah dinilai oleh pengamat mencapai rata-rata $82,7 \%$. Sedangkan pada saat kegiatan siswa yang terjadi di saat penelitian berlangsung berdasarkan hasil dari yang didapatkan memperoleh hasil pada siklus I rata-rata $84,5 \%$. Hasil yang didapat dari kedua penelitian tersebut menunjukkan bahwa kegiatan yang terjadi pada saat penelitian didalam kelas berjalan dengan lancer dan dapat di kategorigan bahwa hasil yang diperoleh pada saat siklus I adalah baik.

Hal-hal yang terjadi pada siklus I ataupun kekurangan yang terdapat pada saat 
penelitian harus menjadi perbaikan pada siklus berikutnya agar penelitian yang dilakukan mampu mancapai ketuntasan pembelajaran yang telah ditetapkan. Selanjutnya diperoleh persentase hasil tes akhir siswa pada siklus II mencapai 92\%, dengan demikian hasil pada siklus II sudah memenuhi kriteria yang diinginkan. Adapun kriteria yang diinginkan yaitu jika rata-rata nilai tes akhir siswa $\geq 85 \%$ dengan nilai skor yang diperoleh siswa $\geq 65$, oleh karena itu hasil yang didapatkan pada saat penelitian yang dilakukan dengan tindakan yang diberikan pada siklus II mampu mencapai hasil penelitian yang sesuai dengan ketuntasan pembelajaran yang telah ditetapkan sehingga proses penelitian tersebut dapat dikatakan berhasil menvapai target yang ditentukan. Hasil observasi yang dilakukan oleh dua orang pengamat pada saat penelitian mampu danmengalami peningkatan pada siklus ke II. Kegiatan aktifitas guru mendapatkan skor persentase rata-rata $95,4 \%$. Kegiatan siswa yang dilakukan pada saat siklus II memperoleh hasil pesentase rata-rata 93,6\%.

Adapun hasil dari kriteria yang didapatkandari kegiatan peneliti dan juga siswa pada siklus II sesuai denga hasil dua orang pengamat yang telah diteliti memperoleh dan masuk dalam kategori baik. Dari beberapa hasil yang telah dteliti oleh pengamat data yang telah diuraikan, maka sesuai hasil yang diperoleh dan yang telah diteliti dangan beberapa rancangan atau susunan kegiatan shingga mampu mencapai keinginan peneliti untuk memperoleh nilai sesuai yang ditentukan, dan memperoleh hasil yang baik sesuai tindakan-tindakan yang telah dilakukan dari segi aktivitas ataupun dari segi hasil yang telah tercapai. Oleh karena itu, penelitian yang dikaksanakan oleh peneliti sudah mencapai tujuan dan tidak perlu lagi tindakan selanjutnya karna prroses penelitian telah berhasil.

Selain itu, diperoleh bahwa siswa lebih mudah menerima pembelajaran pada materi trigonometri dengan metode ekspositori yang dapat meningkatkan kemampuan koneksi matematis pada siswa. Berdasarkan hasil wawancara yang didapatkan dari yang diwawancarakan diperoleh bahwa hasil penelitian yang digunakan metode ekspositori mampu meningkatkan kegiatan pembelajaran yang bertujuan untuk meningkatkan kemampuan koneksi matematis siswa dan keberhasilan ini juka menunjukkan bahwa siswa senang dalam proses penelitian tersebut.

Analisis data menunjukkan bahwa metode ekspositori yang telah dilaksanakan di kelas $X$ IPA 1, MAN 1 Bireuen tahun ajaran 2020/2021 mampu meningkatkan kemampuan koneksi matematis siswa pada materi trigonometri. Dengan demikian berdasarkar hasil diatas dapat disimpulkan bahwa keberhasilan penelitian yang dilakukan oleh peneliti mampu mencapai indikator kemampuan koneksi matematis siswa tercapai dengan menggunakan metode ekspositori kelas X IPA 1 di MAN 1 Bireuen,

$\frac{\text { skor yang diperoleh siswa }}{\text { skor maksimal soal }} x^{100 \%}$

Perubahan dari kedua siklus tersebut yang mengalami peningkatan dari siklus I dan meningkat pada siklus ke II dapat digambarkan pada diagram dibawah ini.

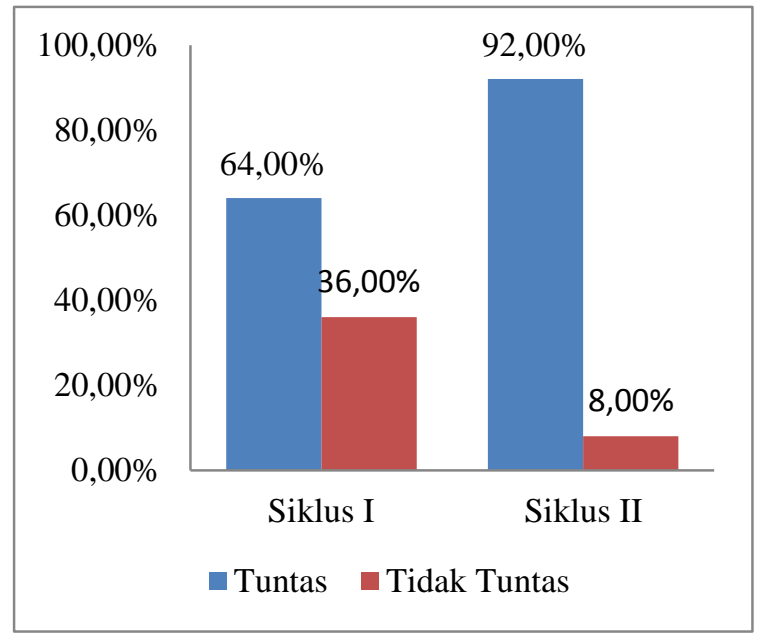

Gambar 3.1. Diagram peningkatan ketuntasan belajar siswa 
Adapun persentase dari aktifitas guru pada saat penelitian dan aktifitas siswa dapat dilihat pada diagram dibawah.

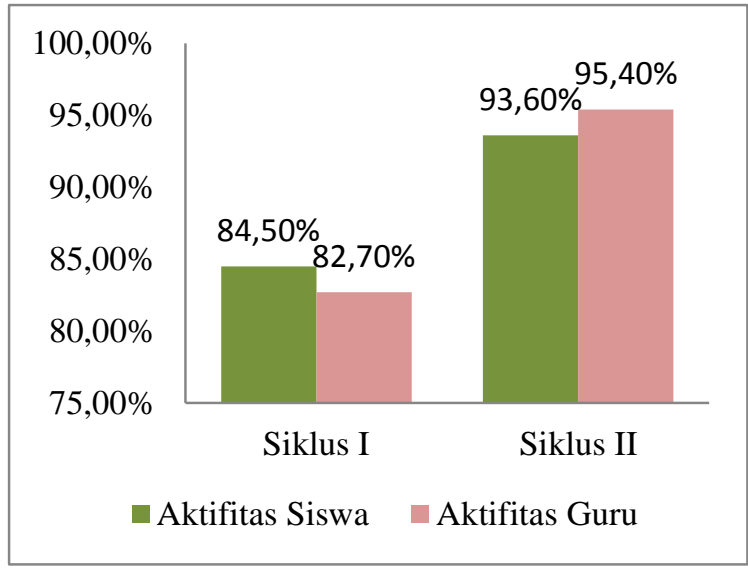

Gambar 3.2. Diagram persentase siklus I dan Siklus II

\section{SIMPULAN}

Dari pelaksanaan penelitian yang dilaksanakan di MAN 1 Bireuen dapat disimpulkan bahwa:

1. Metode ekspositori meningkatkan kemampuan koneksi matematis siswa pada materi trigonometri kelas $\mathrm{X}$ di MAN 1 Bireuen.

2. Aktivitas belajar siswa semakin meningkat pada materi trigonometri dengan menggunakan metode ekspositori pada kelas X di MAN 1 Bireuen.

3. Metode ekspositori dapat meningkatkan taraf keberhasilan pada proses pembelajaran baik aktivitas guru maupun aktivitas siswa.

\section{DAFTAR PUSTAKA}

Arikunto, S. (2012). Penelitian Tindakan Kelas. Bumi Aksara.

Dewi, N. R. (2013). PENINGKATAN KEMAMPUAN KONEKSI MATEMATIS MAHASISWA MELALUI BRAIN-BASED LEARNING BERBANTUAN WEB. Prosiding SNMPM Universitas Sebelas Maret, 1.

Novianti, N., \& Khaulah, S. (2021). PENERAPAN MODEL PEMBELAJARAN MIND MAPPING TERHADAP PENINGKATAN KEMAMPUAN KONEKSI MATEMATIS SISWA PADA MATERI PROGRAM LINEAR DI KELAS XI MAN PEUSANGAN. Jurnal Variasi, 13(Nomor 1), 26-29. https://doi.org/https://doi.org/10.51179/vrs.v $13 \mathrm{i} 1.502$

Sanjaya, W. (2019). Strategi Pembelajaran Berorientasi Standar Proses Pendidikan. Kencana.

Suyitno, A. (2004). Dasar-dasar dan Proses Pembelajaran Matematika I. Semarang: UNNES. 